\title{
INVESTIGATING THE PROFESSIONAL COMPETENCY AND REFLECTIVE PRACTICES OF STATE ISLAMIC PRIMARY SCHOOL ENGLISH TEACHERS
}

\author{
Hery Rahmat \\ UIN Mataram, heryrahmat@uinmataram.ac.id
}

\begin{abstract}
Continuous teacher reflection is a part of the teachers' education literature. However, in practice, teachers rarely carry out selfreflection processes to make a number of improvements toward their professional performance. For this reason, this research aimed to unveil (1) the professional competency of State Islamic Primary School English teachers in Mataram in teaching; (2) the reflective practices of these teachers to improve their professional competencies in teaching. This qualitative descriptive research, which garnered the data through observations, interviews, and documentation, and in which the collected data were analyzed through three different phases: data reduction, data verification, and (3) conclusion, uncovered that the professional competency of the State Islamic Primary School English teachers in Mataram teaching was relatively good as indicated by the implementation of three learning activities: introduction activity, main activity, and closing activity with the supported activities. Other empirical evidence also showed that there were three types of reflective practices made by the English teachers in teaching, namely (a) the use of learning media; (b) the addition of score exercise; and (c) the changing of content exercises.
\end{abstract}

Keywords: Reflective Practices, Professional Competency.

\section{INTRODUCTION}

The progress of a nation is largely determined by the quality of resources possessed by both natural resources and human resources. Progress will be achieved when supported by adequate 
quality and quantity of both resources, whereas progress will be hampered if the resources are limited and in poor quality. Creating human resources is inseparable from educational factors because education is a long-term investment in human resources that has a strategic value for the continuity of human civilization. But the aspect of education is a large area whose scope includes all human experience and thought about education. Republic of Indonesia Law Number 20 of 2003 about the national education system states that what is meant by education is a conscious and planned effort to create a learning atmosphere and learning process so that students actively develop their potential in order to have religious spiritual strength, self-control, society, nation and state (Sudjana, 2010). In order to achieve these educational goals, the role of a teacher as the spearhead in the learning process becomes very important. It is through teachers' hand the task to develop the nation's children so that they can do the best for the country in the future (Isjoni, 2008).

A professional teacher is required to have teachers' skills called competence. By having competencies related to their duties and responsibilities, teachers are expected to be able to carry out their duties professionally. According to the Ministry of National Education, competence is the ability to behave, to think and to act consistently as an embodiment of knowledge, attitudes and skills possessed by students. In other words, competency is a performance capability motivated by the mastery of knowledge, attitudes and skills (Depdiknas, 2006).

Teacher's competencies according to Article 10 of Law Number 19 Year 2005 concerning Teachers and Lecturers include pedagogic competencies, personality competencies, social competencies, and professional competencies. To be more specific, a teacher needs to develop adequate knowledge about the subject matter. It urges the need to develop the professional competence. As a demand for professionalism, a teacher is required to master the fields of science, teaching materials, learning methods, motivating students, having high skills and broad insight into the world of education. In addition, a teacher must also have a deep understanding of the nature of humans and society. 
Rahmat, H., Investigating the Professional...

English as an international language plays an important role as communication means toward the world, as well as in absorbing science and technology. One aspect that needs to be mastered by students is the ability to speak good English, (oral and written). In addition students must master all four language skills as well as vocabulary and grammar (Deff, 1968).

This has been the reason why English is taught from the beginning level. It starts with the implementation of the Kurikulum Tingkat Satuan Pendidikan (KTSP) which implies English subject from elementary level (SD/MI). This policy has been welcomed by academics and practitioners especially those involved in foreign languages learning. Unfortunately the government thorugh Kurikulum 2013 has eliminated English subjects at the level of $\mathrm{SD} / \mathrm{MI}$ although some people regretted it. However, this does not rule out the possibility that children in elementary level cannot learn English. A number of SD and MI, both public and private with their respective policies, make English as a subject of Muatan Lokal. The condition also occurs in Mataram. According to Ms. Diah, one of the heads of private MI in Mataram, English subjects is still needed for students as it will ease the English teachers in Junior High School (SMP/ MTs) in terms of introducing materials. In addition, with the status of Lombok Island as a tourist destination, the position of English as a communication tool has become more important. Furthermore, it was stated that out of 24 MIs in Mataram, there are still 17 MIs who still gave English subjects though only as Muatan Lokal.

The success of English subject is greatly influenced by the ability of teachers to carry out learning. One step for teachers to improve their professional roles and responsibilities is by having self reflection. According to Harmer, being a reflective teacher means constantly reflecting on what has been done. Keep thinking about what we have done and why (Harmer, 2007). Richards \& Lockhart (1996) also mentioned that the teachers' approach in which they explored what they have done and its' reason was part of a reflective approach in teaching.

Thus continuous teacher reflection is part of the teachers' education literature. However, in practice, teachers rarely carry out 
self-reflection processes to make a number of improvements toward their professional performance. In fact reflection can be used as the main literature for teacher in developing new strategies to solve the problems of the teaching and learning process so that culturally it becomes a reference in the development of professional practice (Howard, 2003).

The preliminary observations showed that English teachers recruited by 3 State Islamic Primary Schools in Mataram were contracted teachers considered eligible to carry out the learning. This suggests the need for teachers' self-evaluation processes, so that the learning can be more successful. Moreover, if it is associated with the implementation of English subject at the level of primary education (MI/SD) which is 'only' as local content, it is beyond the demands of times which continue asking teachers to do more than they have ever gotten from their teachers in the past. The gap shows the importance of exploring the professional competence of English teachers in MINs and how MIN's English teachers have done reflective practices to improve their professional competence.

The phenomena has led the researcher to conduct a reserach which problems are stated to answer the following questions. (1) How was the professional competency of the State Islamic Primary School (MIN) English teachers in teaching? (2) What were the reflective practices of these teachers to improve their professional competencies in teaching? In accordance with the research problems, this research aimed to unveil (1) the professional competency of State Islamic Primary School English teachers in Mataram in teaching; (2) the reflective practices of these teachers to improve their professional competencies in teaching.

\section{LITERATURE REVIEW \\ The Nature of Competence}

In general competence is a rational behavior to achieve the required goals according to the expected conditions. According to W. Robert Houstan as cited in Samana (1994) stated that a person who is declared competent in a particular field is a person who controls the work skills concerned and thus has the demands of 
authority in the social service of the community. Competence is the main component of professional standards in addition to the code of ethics as a regulation of professional behavior stipulated in certain procedures and supervision systems. Competencies are interpreted and interpreted as effective behavioral devices that are related to exploration and investigation, analyzing and thinking, and providing specific attention and goals effectively and efficient (Mulyasa, 2008).

Based on the description above, competency is defined as the ability to master knowledge, skills, attitudes, and those who carry out professions specifically in the teaching profession. In this case teacher competence is the ability of a teacher to carry out his obligations responsibly in carrying out his profession as a teacher (educator and teacher).

\section{Teacher Competence}

Professional teachers will work to implement the functions and objectives of the school in particular and the purpose of general education, must have the competencies required to be able to carry out their duties properly. According to Hamalik (2002), the teacher is called competent professionally, if the teacher (a) Able to develop responsibilities as well as possible; (b) Able to carry out roles successfully' (c) Able to work in an effort to achieve educational goals in school; (d) Able to carry out his role in the teaching and learning process in the classroom.

To become a teacher must have academic qualifications and achieve set competency standards. For this reason, the teacher must have four types of competencies, namely pedagogic competence, personality competence, social competence, and professional competence (Siswoyo, 2007). Pedagogic competence is the ability to manage learning in the form of understanding of students, designing and implementing learning, evaluating learning outcomes, and developing students to actualize their various potentials. Personality Competence is the ability in the form of a personality that is solid, noble, wise, and authoritative and an example of students. Professional competence may form in 
mastering subject matter widely and deeply. While social competence is the ability to communicate and interact effectively.

\section{Teacher Professional Competence}

A professional teachers must meet 3 domains of standards. The three domains are: (a) cognitive standards for example mastering learning material, mastering various methods according to the material; (b) affective standards, for example having selfesteem, high concern in the development of education and broad insight into change; (c) and psychomotor standards, for example mastering skills in the field of study (Paraba, 2000). The scope of professional competence in general is: (a) Understand and can apply the educational foundation; (b) Understand and can apply learning theory according to the students' development; (c) Able to handle and develop his/her field of study; d) Understand and can apply various learning methods; e) Able to develop and use various media tools and resources; f) Able to organize and implement learning programs; g) Able to carry out evaluation of learning outcomes; and h) Able to grow the students' personality (Mulyasa, 2007).

Sukanti (2008) stated that professional competence is the mastery ability of learning material widely and deeply to guide students which includes: a) mastering the substance of the field of study and scientific methodology; b) master the structure and curriculum material of the field of study; c) master and utilize information and communication technology in learning; d) organize curriculum subject areas; and e) improve the quality of learning through classroom action research.

\section{Teacher Professional Competence through Learning}

One factor that strongly influence learning success is the learning process. Therefore, to understand and to implement learning procedures are some obligation for teacher. In general the learning devides into three stages as follows: (1) pre-learning or initial learning activities; (2) core learning activities; and (3) final learning activities. Each of these stages is carried out systematically, effectively and efficiently. The learning procedure is a sequential 
Rahmat, H., Investigating the Professional...

process in shaping the ability of students in accordance with predetermined goals.

According to Winataputra et al. (2003) in the learning process, there are 3 stages that are carried out, namely: (1) Introduction; (2) Core activities; and (3) Final activities and followup learning. The three stages are described as follows.

1. Introduction

During this preliminary activity there are several things that teacher can do namely (a) Creating the initial conditions of learning which includes fostering familiarity, creating learner readiness, and creating a democratic learning environment; and (b) Apperception / pretest, includes asking questions related to the previous material, giving comments on the answers of students, and arousing motivation, and attention of students to take part in learning activities.

2. Core Activities

During the core activities, teacher needs to carry out the following activities: (a) Conveying the goals to be achieved whether by oral or in writing; (b) Delivering alternative learning activities that will be taken; and (c) Discussing the materials

3. Final Activity and Follow-Up Action for Learning

During the closing activity, teacher may carry out the following activities: (a) Final assessment; (b) Analysis of final assessment's results; (c) Follow-up; (d) Presenting the topic that will be discussed next; and (e) Closing learning activities.

\section{Self-Reflection and Teachers' Professionalism Development}

Self-reflection activities are activities that provide many benefits in developing teacher professionalism (Loughran, 2005). This helps teachers to gain a deeper understanding of themselves, the profession and how they can become effective, efficient, and successful teachers in learning. In addition, self reflection also helps teachers to explore their potential, improve weaknesses and find solutions needed for professional development. Therefore selfreflection contributes highly to helping teachers in developing their professionalism, and leads to increasing the competence of students. Futhermore reflection is important to fulfill the breadth 
and depth of teacher professional knowledge. There are three elements of professional knowledge that are self-reflection material, namely: 1) content knowledge; 2) pedagogical knowledge; and 3) knowledge of content packaging in meaningful learning.

Korthagen \& Vasalos (2005) menitioned 4 aspects of teacher reflection in their professional practice, namely: 1) Environment, namely how to use the learning environment; 2) Professional behavior, such as a positive response to change or innovation; (3) Competence, especially response to the importance of increasing professional competence; and (4) Teacher's belief about his profession.

\section{Approaches to Reflective Practice}

Years ago, Dewey called on teachers to take reflection that requires "active, persistent, and careful consideration of any expected beliefs or forms of knowledge in light of the basis that supports them and the further consequences they cause". Dewey identified three reflective attributes, namely: (1) Open-mindedness, namely the desire to listen to more than one side of the problem and pay attention to alternative views; (2) Responsibility (responsibility), namely the involvement of careful consideration of the consequences caused by action; and (3) Wholeheartedness which implies efforts to overcome fear and uncertainty to critically evaluate their practice to make meaningful changes. (Farrell, 2008). Farrell (2007) also mentioned that reflective practice in the professional development of teachers is based on the teacher's ability to improve teaching consciously and systematically by reflecting teaching experience. Menawhile Valli (1997) suggested that teachers can "look back on events, make self-assessments, and change teaching behavior in terms of crafts, research, and ethical knowledge". Finally Richards \& Lockhart (1995) said that teachers can use their classroom experience as a basis for critical reflection if the teacher can capture thoughts and reactions to information about the event itself. So that the teacher can develop strategies for intervention or change, depending on their needs.

\section{Teaching English for Children}


English is studied in Indonesia as the first foreign language to be taught officially in schools. The use of English is limited such as in class, English news programs on television, international seminars, and for singing. But teaching foreign languages for children is complex and not easy. For this reason, adequate teacher qualifications are needed from teaching skills, creativity, thorough preparation, classroom management, and patience. In addition the teacher must be able to provide examples or be able to act as a model as a foreign speaker so that the child can imitate the words, phrases or sentences that are commonly used in communication (Suyanto, 2007).

English teachers need to know and master knowledge about how children learn languages so that they can teach more effectively. In terms of teaching English for children in Indonesia, a good understanding of various concepts of children's language learning will determine the success and effectiveness of learning English for children. Good understanding makes us able to evaluate learning methods or techniques that are ordinary and we can apply.

\section{Related Studies}

The research conducted by Bujang Rahman (2014) aimed to see the extent of self-reflection by teachers contributed the effort to develop teacher professionalism. There were 120 elementary school teachers in Lampung were involved in the research. The results showed that teacher self-reflection significantly contributed positively toward professional behavior and the efforts to develop teacher professionalism amounted to $35.1 \%(\mathrm{p}<0.05)$. In other words, if teacher self-reflection is done well, then efforts to develop professionalism are also good.

The research conducted by Lanjar Utami (2015) aimed to explain the implementation of the Collaborative Study Group (CSG) to develop teachers' professional competencies and to measure the influence of CSG implementation on the development of teacher professionalism. The study was carried out at the Islamic Senior High School (MAN) Karanganyar in Central Java. The research was designed by Participatory Action Research. The 
subjects of the study were 7 English teachers at MAN Karanganyar. The data was obtained from tests, participant observation, in-depth interviews, questionnaires and document analysis. The researcher used descriptive statistics to analyze quantitative data, and a constant comparative method for qualitative data. The results of the study stated that the implementation of CSG is effective when the principles of andragogy theory are applied and CSG fosters the development of teacher professionalism. This implies that CSG is very important in developing teacher professional competence.

The research conducted by Hassan H. Tairab (2003) aimed to explore ways to increase the professionalism of four elementary school candidates at The College of Education, United Arab Emirates University through reflection during the teaching practice period. This study used analysis in reflection reports written by participants and a discussion in the form of an interview, which involves pre-school discussion and post-study. The Schon formation models are used to analyze participants' written reflection reports. The three main findings of the study are: 1) reflection is raised by changing attention during the teaching practice period; 2) reflection is characterized by the reshaping nature that occured during the teaching practice period; and 3) participant reflection is facilitated by time, opportunity and support obtained during the teaching practice period. The research implied that reflection should be regarded as a serious methodology for the growth and the professional development of prospective elementary school teachers. By learning through the reflection practice elementary school candidates may become professionals in the world of pedagogy.

\section{RESEARCH METHOD}

This research belongs to qualitative research with a descriptive approach where the data collected comes from interview texts, field notes, personal documents, memo notes and other official documents. Therefore, researcher will juxtapose empirical reality (research data) with the corresponding theory so 
Rahmat, H., Investigating the Professional...

that the results of this study can strengthen these theories or even provide a new perspective in the study of related theories.

This research was conducted in 2 State Primary Islamic Schools (MIN) in Mataram, namely MIN 1 Kota Mataram; and MIN 3 Kota Mataram. There are some considerations for location selection namely 1) Both locations provide English lessons; 2) Both locations have permanent English teachers; 3) Both locations are MIN in Mataram with adequate infrastructure; 4) Both locations are easily reached by researcher; and (5) Both locations can be entered by the researcher.

The data source of this study is divided into primary data sources and secondary data sources. The primary data source of this study were 2 English teachers at each MIN. The secondary data sources in this study are madrasah heads and students and learning documents. In order to get focused data, the researchers took the upper class (grades 4, 5, and 6) in each study location.

Data collection in this study uses several techniques namely: (1) Observation, (2) Interview, and (3) Documentation. Each technique will be explained as following. This study uses structured observation guidelines to observe how teachers reflect on the learning that has been done in English subjects by looking. The observation guidelines can be seen in Appendix 1. This observation guide will help the researcher to know teachers' activities from the Introduction Activity (KPd) to the Closing Activity (KPt). Some important notes from observations will be clarified through followup interviews after the learning is complete. Furthermore, the results of these observations will be transformed into narrative forms in order to provide an overview of the learning process observed.

The Interviews used in-depth interviews. After learning, the researcher interviewed the teacher about the notes found during the learning process as a form of teacher reflection on learning. With this technique the researcher asks for teacher comments on the teaching and learning process, especially those related to the Reflective Practice conducted by the teacher. To facilitate data transcription, researchers recorded interviews. Documentation is a way to obtain data sourced from written data, such as laws and 
regulations, school profiles, etc. as supporting data for teacher competence.

The data analysis of this study uses 3 steps, namely: (1) Data Reduction, where researchers collect all data obtained, both from primary sources and from secondary sources; (2) Data Verification, namely the researcher selects and sorts, selects and classifies the data that has been collected from the implementation of the research to verify which data matches the problem and which does not; and (3) Conclusion where data has been collected, selected, grouped, and interpreted by researchers based on data and theory then provide conclusions based on needs..

\section{FINDINGS AND DISCUSSION}

\section{Teachers' Professional Competence in Teaching}

From the results of the analysis, it is known that the professional competence of teachers in carrying out the learning process was relatively good. This can be seen in the implementation of the learning process based on the activities stages supported with their sub-activities as following.

a. Introduction Activities

Through this activities teacher used two types of activities namely (1) Creating the initial conditions of learning and (2) Apperception. During creating the initial conditions of learning teachers perform two activities namely (a) Creating an attractive classroom atmosphere; and (b) Creating student learning readiness. Meanwhile during Apperception teachers perform two activities namely: (a) Asking about the previous material; and (b) Giving comments on students' answers.

b. Core activities

Through this activities teacher used three types of activities namely (1) Delivering the goals to be achieved; (2) Delivering learning activities to be carried out; and (3) Discussing the material. During delivering the goals to be achieved teachers mention any objectives to be focused during the class. Thus during delivering learning activities to be carried out teachers perform four activities namely (a) Asking students to pair up with their peers; (b) Asking students to answer questions using English and Indonesian in cross 
Rahmat, H., Investigating the Professional...

section; (c) Asking students to come to the front of the class; and (d) Asking students to repeat the mentioned vocabulary. Meanwhile during Discussing the material teachers perform three activities namely (a) Discussing material with varied question and answer; (b) Discussiing material in pairs; and (c) Discussing material individually by assignments.

c. Closing Activities

Through this activities teacher used four types of activities namely (1) Final assessment. During this period teachers perform two kinds of assessment namely (a) oral and (b) written assessment; (2) Follow-up activities. During this period teachers ask the students to continue the unfinished exercises for their homework; (3) Presenting the the next topic. During this period teachers usually inform what will be discussed at the next meeting; and (4) Closing the learning activities. During this period teachers perform two kinds of assessment namely (a) greetings as well as thanking; and (b) Extra training.

Looking through the description can be said that the professional competence of English teachers in the State Islamic Primary School 1 Kota Mataram and 3 Kota Mataram in the learning process has been quite good. This is indicated by the implementation of 3 learning activities with supporting activities. This is expected to improve learning in English subjects. This is in accordance with the statement of Harsono and Sofyan Arif (2010) who mentioned that professional competence is the ability to master the subject matter widely and deeply. In this case, it is required to master the knowledge in the field of study and the critical steps to deepen the contents of the field of study based on Competency Standards and Basic Competencies.

\section{Teacher's Reflective Practice in Teaching}

From the results of the analysis, there are three types of reflective practice in the English language subject of research in carrying out the learning process. The three types of reflective practice are (1) the use of learning media; (2) Add training scores; and (3) Change in training material. The following will describe the discussion of each reflective practice found. 
a. The use of learning media.

The study shows that the use of wall clock media prepared by the teacher facilitates understanding as well as increasing students' motivation and focus in learning. This is in accordance with what was stated by Arsyad (2011) who emphasized that the learning process can become more dynamic and will achieve the desired goals if added tools or media, such as audio-visual media, print, projectors, films, games, and so on. Shin (2006) also revealed that one way to increase students' attention and involvement in learning activities required the existence of supporting tools in the form of visual aids, toys, dolls or other colorful objects, which were in accordance with learning, so language learning became easier to understand.

b. Giving additional score

The study shows that giving additional scores has increased students' motivation in answering teacher questions. In this case the motivation given is extrinsic motivation in the form of teacher scores on additional training. It supports Ur (1996) who claimed that where this motivation has the power to foster a person's natural curiosity, develop competence and maintain one's stability in developing self-confidence. Futher external motivation comes from curriculum, competition, community expectations and so forth.

c. Changing in exercises' material.

The study showed that changes in exercise material by adjusting the questions had made it easier for students to answer questions. This is in accordance with what was stated by Muhammad Rohman and Sofan Amri (2013) which is one of the principle principles of material development, namely the material has the principle of relevance, meaning relevance. Learning material should be relevant to the achievement of competency standards, basic competencies and content standards. For example, if the competencies expected by students are in the form of memorizing words, then the learning material taught is in the form of facts.

\section{REFERENCES}


Rahmat, H., Investigating the Professional...

Deff, A. (1968). Teach english. British: Cambridge University Press. Arsyad, A. (2011). Media pembelajaran. Jakarta: PT. Rajagrafindo Persada.

Beijaard, D., Meijer, P. C.; \& Verloop, N. (2004). Reconsidering Research on Teachers' Professional Identity, Teacher and teacher education, 20,(2), 107-128.

Rahman, B. (2014). Refleksi Diri dan Peningkatan Profesionalisme Guru. Jurnal Pedagogia, 90(3), 444-451.

Bowman, B. (1989). Self-Reflection as an Element of Professionalism. The Teachers College Record, 90(3), 444-451.

Cameron, L. (2003). Teaching languages to young learners. Cambridge: Cambridge University Press.

Sudjana, D. (2010). Pendidikan nonformal: Wawasan sejarah perkembangan filsafat dan teori pendukung serta azas. Bandung: Falah Prodution.

Depdiknas. (2006). Peraturan Menteri Nomor 23 Tabun 2006 Tentang Standar Kompetensi Lulusan.

Siswoyo. (2007). Ilmu pendidikan. Yogyakarta: UNY Press.

Mulyasa, E. (2007). Standar kompetensi dan sertifikasi guru. Bandung: Rodakarya.

Paraba, H. (2000). Wawasan tugas tenaga guru dan pembina PAI. Jakarta: Rosdakarya.

Harmer, J. (2007). The practice of English language teaching (4th ed.). Essex: Pearson Education Limited.

Harsono dan Sofyan Arif. (2010). Pengembangan profesionalisme guru. Surakarta: FKIP-UMS.

Howard, T.C. (2003). Culturally Relevant Pedagogy: Ingredients for Critical Teacher Reflection. Theory into Practice, 42(3), 195202.

Isjoni. (2008). Guru sebagai motivator perubahan, Yogyakarta: Pustaka Pelajar.

Korthagen, F., \& Vasalos. (2005). A. Levels in Reflection: Core Reflection as a Means to Enhance Professional Growth. Teachers and Teaching, 11(1), 47-71.

Kothari, C. R. (2004). Research methodology, method and technique, (2nd ed.). New Delhi; New Age International (P) Ltd., Publishers. 
Lang, Q. C., \& Wong, A. F. L. (2006). Engaging beginning teachers. Singapore: Pearson Education Ltd.

Loughran, J. J. (2005). Developing reflective practice: Learning about teaching and learning through modelling. Bristol: Falmer Press.

Usman, M. N. (2012). Manajemen peningkatan mutu kinerja guru: Konsep, teori dan model. Jakarta: Cipta Pustaka Media.

Moleong, L. J. (1993). Metodologi penelitian kualitatif. Bandung: Remaja Rosdakarya.

McKay, S. L. (2002). The reflective teacher: A guide to classroom research. RELC Portfolio Series 3. Singapore: SEAMEO RELC.

McMillan, J. H. \& Schumacher, S. (2001). Research in education: A conceptual introduction (5th ed.). New York: Addison Wesley Longman, Inc.

Mulyasa. (2008). Standar kompetensi sertifikasi guru. Bandung: Remaja Rosdayakarya.

Nasution, S. (1998). Metode penelitian naturalistik kualitatif. Bandung: Tarsito.

Nunan, D. (1992). Research methods in language learning. Cambridge: Cambridge University Press.

Hamalik, O. (2002). Pendidikan guru berdasarkan pendekatan kompetensi. Jakarta: Bumi Aksara.

Richards, J. C., \& Lockhart, C. (1996). Reflective teaching in Second Language classroom. Cambridge: Cambridge University Press.

Samana. (1994). Profesionalisme keguruan. Yogyakarta: Kanisius.

Hawanti, S. (2014). Implementing indonesia's english language teaching policy in primary schools: the role of teachers' knowledge and beliefs. International Journal of Pedagogies and Learning, 9,(2), 162-170.

Sardiman, A.M, (2000). Interaksi dan motivasi belajar mengajar. Jakarta: Raja Grafindo Persada.

Shin, J.K. (2006). Ten Helpful Ideas for Teaching English To Young Learners. English Teaching Forum, 44(2), 2-7.

Sugiyono, (2012). Metode penelitian pendidikan: Pendekatan kuantitatif, kualitatif, dan R\&D. Bandung: Alfabeta.

Sukanti. (2008). Meningkatkan Kompetensi Guru melalui Pelaksanaan Tindakan Kelas. Jurnal Pendidikan Akutansi Indonesia, 6(1), 87 - 93 
Rahmat, H., Investigating the Professional...

Suyanto, K. K. E. (2007). Buku materi pokok: English for children. Tangerang: Penerbit Universitas Terbuka.

Winataputra. (2003). Strategi belajar mengajar. Jakarta: Pusat Penerbitan Universitas Terbuka.

Ur, P. A. (1996). Course in language teaching: Practice and theory Cambridge: Cambridge University Press.

Utami, L. (2015). Pengembangan Kompetensi Profesional Guru melalui Collaborative Study Group (CSG). Seminar Nasional Pendidikan UNS \& ISPI Jawa Tengah

Wallace, M. J. (1991) Training foreign language teachers. A reflective approach. Cambridge: Cambridge University Press. 